\title{
REVOLUSI SOSIAL MASYARAKAT TURKI: Dari Sekularisme Attatur Menuju Islamisme Erdogan
}

\author{
Arrasyidin Akmal Domo \\ Pasca Sarjana Universitas Islam Negeri Sultan Syarif Kasim Riau, Pekanbaru, Indonesia. \\ email:arrasyidinsukses1@gmail.com \\ Nurhasanah Bakhtiar \\ Universitas Islam Negeri Sultan Syarif Kasim Riau, Pekanbaru, Indonesia. \\ Email: nurhasanah.bakhtiar@uin-suska.ac.id
}

Zarkasih

Universitas Islam Negeri Sultan Syarif Kasim Riau, Pekanbaru, Indonesia. Email: zarkasih@,uin-suska.ac.id

\begin{abstract}
Abstrak
Turki, yang pernah tercatat sebagai salah satu dinasti Islam terbesar dalam sejarah mengalami jatuh bangun dan perubahan kebijakan politik yang luar biasa sampai saat ini. Sekularisasi Turki oleh Mustafa Kemal Attatur pada tabun 1924, yang pada awalnya bermaksud untuk kamajuan Turki, namun ternyata menjadi momok yang membahayakan eksistensi Islam di Turki. Kemunculan Erdogan sebagai pemimpin Turki menjadi titik cerah kebangkitan Islam kembali muncul di Turki. Penelitian ini bertujuan untuk menganilisis proses sekularisasi yang dilakukan Mustaf Kemal Attatur dan usaha Kebangkitan Islam oleh Erdogan serta dampak yang ditimbulkannya. Penelitian ini merupakan penelitian kepustakaan (Library Research), dengan mengkaji sumber data dari berbagai literatur baik artikel jurnal maupun buku. Analisa data yang digunakan dengan pendekatan kualitatif melalui content analisis. Pada penelitian ini, penulis menemukan babwa proses sekularisasi yang dibangun oleh Mustafa Kemal Attatur dengan cara mengadopsi kemajuan dan budaya Barat di Turki. Simbol-simbol Islam diganti dengan model dan gaya bidup Barat. Kebijakan ini telah memudarkan bahkan mengebiri eksistensi Islam di Turki. Sejak. kematian Kemal, Para kemalis yang melanjutkan faham yang diajarkan Mustafa Kemal tidak mendapat respon baik dari masyarakat Turki. Para militer yang dulu panatik terhadap faham sekularisasi yang diajarkan Mustafa Kemal Attaur sudah berubah, mereka tidak menjadi nasionalis yang membabi buta, namun telah loyal kepada negara dan penguasa yang sah. Turki saat ini telah memasuki era baru, kelompok Islamis moderat yang menguasai jalannya pemerintahan menunjuk.kan kemajuan diberbagai bidang. Perubahan konstitusi sedikit demi sedikit dilakukan untuk mengurangi babkan menghilangkan peran militer yang besar di dalam politik. Munculnya tokohtokoh Islam yang berada dipemerintahan mampu merubah negara sekuler menjadi negara yang menjunjung tinggi Islam dan bahkan saat ini, Turki bersama Erdogan telah menjadi kekuatan yang diperhitungkan di Dunia. Erdogan muncul sebagai sosok yang mengusung Partai Konservatif dan Religius yang relatif dapat diterima oleh semua kelompok. Babk.an kejayaan Erdogan mampu mengantarkan partai AKP untuk memenangkan pemiliban 3 kali berturut-turut. Sehingga dalam waktu yang relatif singkat, Erdogan mampu mengubah wajah Turki, dari sekularisasi menjadi kebangkitan Islam di Turki.
\end{abstract}

Kata Kunci: Sekularisasi, Mustafa Kemal Attatur, Kebangkitan Islam, Erdogan.

\begin{abstract}
The decline of the Ottoman Empire until it became the State of the Republic of Turkey in 1924 was a disaster for Muslims. Since then the Islamic empire has no protectors, and has even become the monthly basis of other European countries. The condition was exacerbated in World War I of the Ottoman Empire which together with Russia, Poland and Germany lost to England, so that the Ingris made an economic vacuum and caused various strife, to appear nationalist figures who tried to take the hearts of the people of Turkey, even making a match for the Caliph forming a National Council to take care of government. From the description of the problem above, the author intends to analyze the secularization carried out by Erdogan, Mustaf Kemal Attatur and usha Kebangkitan Islam. Turkey turned into a Republic with its first president Mustafa Kemal Attatur, instilled secularization in the Turkish state and alienated Istamic values from the people, because Islam was considered the cause of the backwardness of the Turkish people, and Mustafa Kemal Attaur easily adopted Western culture for Turks. After Mustafa Kemal Attatur's death, the Kemalists still continued and maintained the secularization ideology inherited by Mustafa Kemal Attur, even the military became part of the guardian ideology brought by Mustafa Kemal Attatur. Until a number of times there was a coup by the military against the government that opposed Kemalism. Until finally, Erdogan emerged as a figure who carried the Conservative and Religious Party which was relatively acceptable to all groups. Even Erdogan's triumph was able to deliver the AKP party to win the election 3 times in a row. So that in a relatively short time, Erdogan was able to change the face of Turkey, from secularization to Islamic revival in Turkey. This paper is a Library Research method, with data sources from journals and books. With analysis using content analysis. In this paper, the author finds that Mustafa Kemal Attatur's secularization foundation has faded, the Kemalists who continue the ideas taught by Mustafa Kemal did not get a good response from Turkish society. The military who were once loyal to the secularization of ideas taught by Mustafa Kemal Attaur had changed, they were not blindly nationalists, but had been loyal to the state and legitimate rulers. Even the Turkish Attatur has now entered a new era, moderate Islamists who
\end{abstract}


control the way the government shows progress in various fields. The constitutional changes are gradually being carried out to reduce or even eliminate the large role of the military in politics. The emergence of Islamic leaders in the government was able to turn a secular state into a country that upholds Islam and even today, Turkey and Erdogan have become a force to be reckoned with in the $W$ orld.

Keywords: Secularization, Mustaf Kemal Attatur, The Rise of Islam, Erdogan

\section{PENDAHULUAN}

Turki merupakan sebuah negara yang sebelumnya lebih dikenal sebagai negara sekuler, hal tersebut tidak lepas dari peran Mustafa Kemal Ataturk dalam menyusupkan ideologi sekuler dan pada tanggal 3 Maret 1924 secara resmi ia menghapus khalifah di bumi Turki.(Muhammad Iqbal, 2010: 111) Bagi Kemal, ikut campurnya Islam dalam berbagai lapangan publik, termasuk politik, telah membawa kemunduran Islam. Kemal membandingkan bahwa Barat berani meninggalkan agama dari lapangan politik dan melakukan sekulerisasi sehingga melahirkan peradaban yang tinggi. Karena itu, kalau Turki mau maju dan modern, tidak ada jalan lain kecuali meniru Barat dengan melakukan sekulerisasi juga. Masyarakat Turki harus di ubah menjadi Barat. (Niyazi Berkes, 1953: 465)

Di bawah kepemimpinan Mustafa Kemal, Turki mendeklarasi diri sebagai negara sekuler, posisi agama berada di ruang privat dengan di bawah kontrol negara. Dan juga Sekularisme bagi Mustafa Kemal adalah pilihan paling tepat untuk membawa Turki menjadi lebih baik, sejajar dengan negara-negara Barat, khususnya Eropa. Gagasan sekularisme semakin kokoh karena, konstitusi Turki dikawal oleh militer, yang berada di bawah kontrol Mustafa Kemal. Militer adalah tangan besi kekuasaannya untuk mendukung gagasannya.

Namun seiring perkembangan yang ada, sekulerisme menjadi faktor merosotnya eksistensi pemerintahan dan masyarakat yang ada di Turki, sehingga hati nurani mereka bergejolak untuk menuju perubahan Turki yang lebih baik lagi dan hal tersebut terlihat ketika secara perlahan kedigdayaan militer dalam mengawal konstitusi warisan Mustafa Kemal perlahan mencair dan mengarah pada perubahan-perubahan yang sesuai dengan kebutuhan dan perkembangan di Turki. $\mathrm{Hal}$ itu juga dijadikan sebagai momentum kebangkitan politik Islam oleh kalangan menengah muslim dan pengusung ide-ide Islam disusul pendirian partai-partai berbasis Islam. Meski demikian, dalam perjalanannya demokrasi ala Turki masih saja didominasi oleh Partai penguasa beraliran nasionalis sekuler, mereka cukup berpengaruh di Mahkamah Nasional, pengikut setia almarhum Mustafa Kemal. Akibatnya, banyak partai-partai berideologi Islam dibekukan karena alasan berideologi yang menurut mereka tidak sesuai dengan konstitusi Turki, di sini intervensi militer juga sangat kuat.

Namun hal tersebut tidak menghalangi para pejuang yang mengusung konsep Islamisme di negara Turki, dimulai dari sosok yang terkenal sebagai tokoh gerakan Islam, dan mendapatkan kehormatan sebagai "Seorang Pejuang Islam", atas perjuangannya yang gigih, tak mengenal lelah, sepanjang hidupnya untuk menegakkan cita-cita Islam di tengah-tengah kehidupan politik Turki yang sekuler. Masyarakat Turki mengenalnya dengan nama lengkap, Necmetin Erbakan. Ia membangun "Gerakan Islamis" di Turki, yang harus menghadapi kehidupan sekuler yang keras, dan kuatnya dominasi militer, yang menjadi 'garda depan' sistem sekuler di negeri yang pernah menjadi pusat kekhalifahan Islam.

Berawal dengan memenangkan pemilu tahun 1996 oleh partai yang dipimpin sendiri dan partai yang mengususngnya yaitu partai Islam Refah, Erbakan kemudian melakukan kerjasama dengan pemimpin Partai Tanah Air, Tancu Ciller, dan kemudian membentuk pemerintahan Turki, dan Erbakan menjadi perdana menteri. Tetapi, umur pemerintahannya tidak panjang, hanya satu tahun, karena dibubarkan militer Turki, yang tidak ingin Erbakan mengembangkan pandanganpandangannya yang Islamis itu, kemudian menjadi sebuah kebijakan Turki. (Peena, 2012) Hal tersebut merupakan kasus penjegalan yang menimpa Necmekin Erbakan tahun 1997 saat memimpin dan merupakan salah satu contoh ketegangan nasionalis-Islamis yang masih saja mewarnai kultur politik Turki. Namun perjuangan Islamisasi di Turki tidak terhenti begitu saja, seperti yang diketahui, murid dari Necmekin Erbakan yaitu Recep Tayyip Erdogan bersama Abdullah Gul memegang tongkat estafet dalam mendirikan partai berbasis Islam. Langkah gigih dari keduanya dalam memeperjuangkan ideologi Islam di Turki memiliki kesamaan dengan guru mereka. Terbukti melalui partai AKP (Adalet Ve 
Kalkinma Partisi, Partai Keadilan dan Pembangunan) yang mereka dirikan pada tanggal 14 Agustus 2001, mendapat apresiasi dari masyarakat dengan melihat perkembangan serta keberhasilnnya berupa pemenangan pemilihan umum pada tahun 2002, 2011, 2014, 2018.

\section{PEMBAHASAN}

\section{Kemunduran Dinasti Turki Utsmani}

Sebagaimana kerajaan-kerajaan yang berdiri dan berkembang didunia Islam, mengalami fase pertumbuhan, perkembangan, mencapai masa kejayaan, lalu menagalami fase kemunduran hingga mengalami fase kehancuran. Begitu pula yang terjadi pada kerajaan Turki Usmani yang diplokamirkan oleh Usman Ilalu mengalami perkembangan dimasa Sultan Muhammad II (Al Fatih), dan mencapai masapuncak kejayaan dimasa Sultan Sulaiman al- Qanuni, hingga mengalami masa kemunduran dan masa kehancuran. (Asmal May, 2005: 550)

Para sejarawan mengatakan bahwa kemunduran kerajaan Turki Usmani dimulai sejak wafatnya Sultan Salim II (1556), sejak itu kerajaan Turki Usmani tidak memiliki sultan-sultan yang diunggulkan. Terbukti bahwa pada abad XVII tahun1571 terjadi pertempuran antara armada laut kerajaan Turki Usmani yang dipimpin oleh sultan salim II dengan armada laut Spanyol, yang dipimpin oleh Don Juan di selat Lipanto (Yunani), yang dalam pertempuaran itu, pasukan armada laut Turki Usmani dapat dpukul mundur,sehingga menyebabkan banyak prajurit Usmani tertawan dan kapal armada laut Usmani dihancurkan. Sehingga dengan kekalahan tersebut, armada laut Usamni bukanlah yang terkuat didunia lagi. Namun kekuatan angkatan darat Usmani masih manjadi kekuatan yang ditakuti Erpoa, namun dibeberapa pertempuran lainnya, angkatan turki pada tahun $1683 \mathrm{M}$ sempat mengepung Wina dibawah pimpinan Perdana Menteri Umar Mustafa, namun berkat bersatunya antara tentara Jerman dan Polandia, tentara turki berhasil dipaksa mundur meninggalkan Wina. Sehingga sejak peristiwa itu makin mempertegas bahwa Kerajaan Turki Usmani sudah berada dalam keadaan lemah. Tak hanya itu, semenjak semakin eratnya hubungan Jerman, Polandia dan Rusia, Kerajaan Turki Usmani bertubi-tubi mengalami kekelahan, hingga dengan kondisi ini memaksa Kerajaan Turki Usmani menangadakan perjanjian atau perdamaian dengan negara-negara Eropa. Tahun 1699 dialakukan perjanjian yang dinamakan per- damaian Karlowith. Akibat dari perjanjian ini, Usmani harus rela melepaskan Translavia (Wilayah Austria), Saladonia, dan Karawatai serta Ukraina. Meskipun sudah dilakukan perjanjian, namun oarang-orang Rusia tetap menaklukkan negeri-negeri yang dikuasai dan ditaklukkan dan ditinggalkan oleh orang Turk, Tar dan muslim lainnya,sehingga pada tahun 1792 M kembali terjadi perperangan antara Rusia dan Usmani, namun kembali Usmani mengalami kekalahan dan terpaksalah Usmani harus mengakui kedudukan Rusia atas kerajaan Tartar. (Asmal May, 2005:551)

\section{Mustafa Kemal Attatur Dan Sekularisasi Turki}

Mustafa Kemal Ataturk lahir dengan nama Mustafa, karena pandai di bidang matematika ia dijuluki "Kemal" yang artinya sempurna dan Ataturk berarti "bapak Turki" sebagai pendiri Turki modern. Lahir pada tanggal 12 Maret 1881 dari seorang ibu bernama Zubaedah, seorang wanita salehah dan Ayah yang bernama Ali Ridha seorang pegawai biasa pada salah satu kantor pemerintah di Istanbul. Ayahnya meninggal pada saat Ataturk masih kecil, sejak itu ibunya menjadi satu-satunya orang tua baginya. Oleh ibunya, pertama-tama dimasukkan ke Madrasah Fatima MollahKadin di kota kelahirannya. Sang ibu menginginkannya sebagai hafiz (penghafal Qur'an) dan boja (guru/ustaz). Namun, Ataturk tidak puas dan memilih keluar kemudian masuk ke sekolah umum (Shemsi Effendi) di Salonika. Setelah menamatkan sekolah dasar dalam usia 12 tahun, kemudian masuk Sekolah Menengah Militer di Salonika. Kemudian melanjutkan pendidikan militernya pada Sekolah Latihan Militer di Montasir. Pada 1898 ia meneruskan studinya pada Sekolah Tinggi Militer di Istanbul hingga mendapat ijazah pada 1905 dengan pangkat kapten. (Nina M. Armando, 2005: 228)

Kehidupan Mustafa Kemal sejak 1905 sampai dengan 1918 diwarnai dengan perjuangan untuk mewujudkan identitas kebangsaan Turki. Sebagai pejabat militer di dalam imperium Turki Usmani saat itu, ia mendirikan sebuah organisasi yang bernama Masyarakat Tanah Air (Fatherland Society) (Jules Archer, 2004: 90). Ia juga bergabung bersama Kongres Turki Muda yang membentuk Komite Kebangsaan dan Kemajuan Committee for Union and Progress (C.U.P). Setelah berakhirnya Perang Dunia I, tepatnya pada tahun 1919 Mustafa Kemal berusaha mewujudkan prinsip-prinsip generasi Turki Muda. Di bawah kepemimpinannya, 
elit nasional Turki berhasil memobilisasi perjuangan rakyat Turki dan melawan pendudukan asing. Rakyat Turki berhasil memukul mundur kekuatan penjajahan dari tanah bangsa Turki, yang secara tidak langsung menjadi kemenangan awal bagi Mustafa Kemal Attaturk. Pada tahun 1920, Mustafa Kemal membentuk Majelis Nasional di Ankara. Melalui gerakan politis dan diplomatis di parlemen Majelis Nasional Agung (Grand National Assembly), di mana dalam parlemen ini Mustafa Kemal menjadi ketuanya, ia berhasil mendirikan rezim republik atas sebagian wilayah Anatolia, memberlakukan suatu konstitusi baru bagi rakyat Turki pada tahun 1920, dan mengalahkan republik Armenia, mengalahkan kekuatan Perancis, dan mengusir kekuatan tentara Yunani. Klimaks perjuangan Mustafa Kemal yang mengantarkannya ke kursi presiden republik Turki adalah ketika bangsa Eropa mengakui kemerdekaan bangsa Turki yang ditandai oleh perjanjian Lausanne pada tahun 1923.

Perang Dunia I berakhir dengan kemenangan pihak Sekutu dan Turki harus menandatangani Perjanjian Sevres (10 Agustus 1920). Golongan nasionalis Turki tidak menyetujui hasil dari Perjanjian Sevres karena merugikan Turki. Reaksi Sekutu terhadap penolakan itu menyebabkan Perang kemerdekaan Turki tahun 1921 hingga tahun 1922. Untuk menyelesaikan masalah tersebut, Sekutu dan Turki melakukan perundingan di kota Lausanne. Perundingan itu menghasilkan Perjanjian Lausanne tahun (24 Juli 1923). Dengan diadakannya Perjanjian Lausanne, maka Perjanjian Sevres dibatalkan. Isi Perjanjian Lausanne adalah sebagai berikut: 1) Thracia Timur (daerah sekitar Konstantinopel) dikembalikan kepada Turki; 2) Turki melepaskan semua daerah yang penduduknya bukan bangsa Turki (Arabia merdeka, Lybia diserahkan ke Italia, Mesir, Palestina, Trans-Jordania, Irak, Cyprus diserahkan ke Inggris dan Syria, Libanon diserahkan ke Inggris); 3) Borporus, Marmora, dan Dardanella terbuka untuk semua kapal asing; 4) Semua "capitulations" (hak-hak ekstra-territorial) dari bangsa asing dihapus, 5) Turki tidak perlu mengurangi angkatan perangnya; 6) Turki tidak usah membayar kerugian perang; 7) Turki harus melindungi minoritas. (Solihun, 2013: 6)

Tepatnya pada tanggal 23 Maret 1924, keruntuhan kekhalifahan Turki Usmani berakhir, keruntuhan Turki Usmani terjadi akibat adanya perseteruan diantara kaum nasionalis dan agamis dalam masalah kemunduran ekonomi Turki. Setelah menguasai Istanbul paska Perang Dunia I,
Inggris menciptakan sebuah kevakuman politik dengan menawan banyak pejabat Negara dan menutup kantor- kantor dengan paksa sehingga bantuan khalifah dan pemerintahannya tersendat. Kekacauan terjadi di dalam negeri, sementara opini umum mulai menyudutkan pemerintahan khalifah yang semakin lemah dan memihak kaum nasionalis. Situasi ini dimanfaatkan Mustafa Kemal Pasha untuk membentuk Dewan Perwakilan Nasional yang berpusat di Ankara, dan ia menobatkan diri sebagai ketuanya. Sehingga ada dua pemerintahan saat itu, pemerintahan khilafah di Istambul dan pemerintahan Dewan Perwakilan Nasional di Ankara. Meskipun kedudukannya bertambah kuat, Mustafa Kemal Pasha belum berani membubarkan khilafah. Dewan Perwakilan Nasional hanya mengusulkan konsep yang memisahkan khilafah dengan pemerintahan. Namun, setelah perdebatan panjang di Dewan Perwakilan Nasional, konsep ini ditolak. Pengusul dari konsep tersebut akhirnya mencari alasan untuk membubarkan Dewan Perwakilan Nasional dengan melibatkannya dalam berbagai kasus pertumpahan darah. Setelah memuncaknya krisis, Dewan Perwakilan Nasional ini diusulkan agar mengangkat Mustafa Kemal Pasha sebagai ketua parlemen, yang diharapkan agar bisa menyelesaikan kondisi kritis ini.

Setelah resmi dipilih menjadi ketua parlemen, Mustafa Kemal mengumumkan kebijakannya, yaitu mengubah sistem khilafah dengan republik yang dipimpin seorang Presiden yang dipilih lewat pemilihan umum. Pada tahun 1923 ia dipilih parlemen sebagai presiden pertama Turki. Akan tetapi niat untuk membubarkan khilafah saat itu, menemui jalan terjal. Di pihak khilafah, yaitu kelompok pendukung Sultan Abdul Majid II tidak pernah setuju dengan pemerintah republik yang dibuat oleh Mustafa Kemal. Ia dianggap tidak sesuai dengan keadaan masyarakat Turki oada saat itu, dan beberapa kelompok pendukung Sultan Abdul Majid II terus berusaha mendukung pemerintahannya. Ancaman ini tak menyurutkan langkah Mustafa Kemal. Akan tetapi, Mustafa Kemel justru menyerang balik dengan taktik politik dan pemikirannya yang menyebut bahwa penentang sistem republik ialah pengkhianat bangsa dan ia kemudian melakukan beberapa langkah kontroversial ntuk mempertahankan sistem pemerintahannya. Khalifah digambarkan sebagai sekutu asing yang harus diperangi. Setelah suasana Negara kondusif, Mustafa Kemal mengadakan sidang Dewan Perwakilan Nasional pada sidang tersebut ia memecat khalifah sekaligus 
membubarkan sistem kekhalifahan dan menghapuskan hukum Islam dari Negara. Hal inilah yang kemudian dianggap sebagai keruntuhan kekhalifahan Islam yang sesungguhnya. Turki menjadi alih fungsi dari kesultanan Ustmani menjadi Negara Turki yang berasaskan republik Turki, dengan Mustafa Kemal sebagai presiden Republik Turki. (Jules Archer, 2004: 93)

Sebagai seorang presiden, dalam menjalankan pemerintahannya ia dinilai sebagai seorang diktator, partai yang boleh hidup di Turki saat itu adalah Partai Republik Rakyat (Cumburiyet Halk Partisi [CHP]), dikenal keras dalam menjalankan gagasan nasionalisme, sekularisme dan westernisme. Sebagai seorang militer, ia memimpin bangsanya seperti layaknya memimpin pasukan, mengeluarkan berbagai perintah untuk menciptakan sebuah negara model Barat modern. Impiannya adalah Turki bisa menjelma sebagai negara kuat, modern dan dihormati. Menurutnya, satu-satunya jalan untuk mewujudkan ide ini adalah dengan jalan melakukan sekularisasi yang pada prakteknya adalah dengan melakukan westernisasi (pembaratan). Bagi Ataturk, kemajuan Turki hanya bisa diraih dengan penerimaan Barat secara total. (Nur Aliyah Zainal, 2016: 22)

Dengan beralihnya menjadi Republik Turki, maka Mustafa Kemal juga melakukan berbagai perubahan, adapun pembaruan Kemal Atatürk dilaksanakan di atas enam prinsip dasar yang menjadi filsafat politik dan dasar Republik Turki. Keenam prinsip dasar atau sering disebut "Nilai Kemalis" adalah: pertama, Republikanisme, bahwa negara Turki modern menerapkan sistem demokrasi parlementer yang dipimpin oleh seorang persiden, bukan kesultanan ataupun khilafah. Kedua, Nasionalisme, tidak berdasarkan agama dan ras tetapi berdasarkan kewarganegaraan yang sama dan mengabdi kepada cita-cita nasional. Ketiga, Populisme, perlindungan hak asasi manusia dan kesetaraan dihadapan hukum. Keempat, Etatisme, pemerintah berkuasa penuh dalam pengelolaan ekonomi dan berhak intervensi demi kepentingan rakyat. Kelima, Sekularisme, menetapkan pemisahan agama dan negara. Keenam, Revolusionalisme, menerima transformasi secara permanen. Dari enam sila ini, sekularisme adalah yang paling berpengaruh. (Arfan Mu'ammar, 2016: 138)

\section{Erdogan Dan Kemajuan Peradaban Islam Turki}

Turki merupakan sebuah negara yang sebelumnya lebih dikenal sebagai negara sekuler, hal tersebut tidak lepas dari peran Mustafa Kemal Ataturk dalam menyusupkan ideologi sekuler di negara yang menjadi perbatasan antara Asia dan Eropa ini. Pada tanggal 3 Maret 1924 secara resmi ia menghapus khalifah di bumi Turki. (Muhammad Iqbal, Amin Husein Nasution, 2010: 111) Bagi Kemal, ikut campurnya Islam dalam berbagai lapangan publik, termasuk politik, telah membawa kemunduran Islam. Kemal membandingkan bahwa Barat berani meninggalkan agama dari lapangan politik dan melakukan sekulerisasi sehingga melahirkan peradaban yang tinggi. Karena itu, kalau Turki mau maju dan modern, tidak ada jalan lain kecuali meniru Barat dengan melakukan sekulerisasi juga. Masyarakat Turki harus di ubah menjadi Barat.

Setelah meniadakan kekhalifahan, politik Kemalisme menghapuskan lembaga-lembaga syariah, meskipun sebenarnya peranan lembaga ini sudah sangat dibatasi oleh para pembaru Kerajaan Usmani. Bagi Kemalis, syariat adalah benteng terakhir yang masih tersisa dari sistem keagamaan tradisional. Lebih lanjut lagi Kemalis menutup sekolah-sekolah madrasah yang sudah ada sejak tahun 1300-an sebagai suatu lembaga pendidikan Islam. Reformasi agama, yang bentuknya upaya Turkifikasi Islam atau nasionalisasi Islam ini merupakan bentuk campur tangan pemerintah Kemalis dalam kehidupan beragama di masyarakat Turki. Sekularisme yang sejatinya memisahkan hubungan agama dengan pemerintahan, di mana negara menjamin kebebasan beribadah, bagi warga negara, pada pelaksanaannya dijalankan dengan semangat nasionalisme yang radikal dan dipaksakan oleh Kemalis. Namun penerapan nasionalisasi agama ini hanya bertahan hingga akhir pemerintahan Kemalis (Partai Rakyat Republik). Sejak tahun 1950, azan kembali diucapkan dalam bahasa Arab. Mesjid-mesjid di Turki pun hingga saat ini tetap menunjukkan bentuk-bentuk yang umum sebagaimana mesjid di negara-negara lainnya. Peradaban menurut Mustafa Kemal, berarti peradaban Barat. Tema utama dari pandangannya tentang pem-Barat-an adalah bahwa Turki harus menjadi bangsa Barat dalam segala tingkah laku. Untuk itu Pemerintah Kemalis mengeluarkan kebijakan larangan menggunakan pakaian-pakaian yang dianggap pakaian agama di tempat-tempat umum dan menganjurkan masyarakat Turki menggunakan pakaian a-la Barat. Sampai saat ini pemakaian topi menghilang bersamaan dengan menghilangnya kebiasaan memakai topi itu pada masyarakat Eropa. (Imron Mustafa, 2016: 56) 
Selain reformasi agama, reformasi yang paling penting dari rezim Kemalis adalah reformasi bahasa. Tulisan Arab diganti dengan tulisan Latin, berdasarkan undang-undang yang diputuskan oleh Dewan Nasional Agung pada 3 November 1928. Tujuan reformasi bahasa adalah membebaskan bahasa Turki dari 'belenggu' bahasa asing. Penekanannya adalah pemurnian bahasa Turki dari bahasa Arab dan Persi. Mustafa Kemal mengadakan kunjungan di banyak tempat untuk mengajar secara langsung tulisan baru pada rakyat Turki. Komite ahli hukum mengambil Undang-undang sipil Swiss untuk memenuhi keperluan hukum di Turki menggantikan Undang-undang Syariah, berdasarkan keputusan Dewan Nasional agung tanggal 17 Februari 1926. Undang-undang Sipil yang mmulai diberlakukan pada tanggal 04 Oktober 1926 ini antara lain tentang menerapkan monogami; melarang poligami dan memberikan persamaan hak antara pria dan wanita dalam memutuskan perkawinan dan perceraian. Sebagai konsekuensi dari persaman hak dan kewajiban ini hukum waris berdasarkan Islam dihapuskan. Selain itu undang-undang sipil juga memberi kebebasan bagi perkawinan antar agama. Pada 1 Januari 1935, pemerintah mengharuskan pemakaian nama keluarga bagi setiap orang Turki dan melarang pemakaian gelar-gelar yang biasa dipakai pada masa Turki Usmani. Mustafa Kemal menambahkan nama Ataturk, yang berarti Bapak Bangsa Turki, sebagai nama keluarga. Pada tahun 1935 sistem kalender hijriyah diganti dengan sistem kalender masehi; hari Minggu dijadikan hari libur menggantikan hari libur sebelumnya yaitu hari Jumat.Tentang sekularisasi dan modernisasi di Turki pada masa Rezim Kemalis seperti diuraikan di atas, Bryan S. Turner, seorang guru besar sosiologi di Universitas Flinders (Australia Selatan), menyimpulkan bahwa sekularisme tersebut merupakan suatu bentuk pemaksaan dari pemerintah rezim, bukanlah sekularisasi yang tumbuh sebagai suatu konsekuensi dari proses modernisasi seperti di negara-negara Eropa. Selain itu sekularisasi di Turki pada saat itu merupakan peniruan secara sadar pola tingkah laku masyarakat Eropa yang dianggap modern dan lebih maju. Meminjam istilah Darver sebagaimana yang dikutip oleh Binnaz Toprakbahwa republik Turki adalah sebuah negara semi sekuler. Bagi Kemalis, manusia Turki baru tidak saja harus berpikiran rasional seperti orang-orang Eropa, tetapi juga harus meniru tata cara berperilaku dan berpakaian seperti mereka. Karenanya tidak salah memang, jika Amien Rais, mengatakan dalam sebuah kata pengantar bahwa satu-satunya negeri Muslim yang pernah melancarkan sekularisasi besar-besaran adalah Turki pada masa Kemal Attaturk, dengan didukung oleh kekuasaan telanjang pemerintah Attaturk. (Imron Mustafa, 2016: 56)

Di bawah kepemimpinan Mustafa Kemal, Turki mendeklarasi diri sebagai negara sekuler, posisi agama berada di ruang privat dengan di bawah kontrol negara. Dan juga Sekularisme bagi Mustafa Kemal adalah pilihan paling tepat untuk membawa Turki menjadi lebih baik, sejajar dengan negara-negara Barat, khususnya Eropa. Gagasan sekularisme semak-in kokoh karena, konstitusi Turki dikawal oleh militer, yang berada di bawah kontrol Mustafa Kemal. Militer adalah tangan besi kekuasaannya untuk mendukung gagasannya. Namun seiring perkembangan yang ada, sekulerisme menjadi faktor merosotnya eksistensi pemerintahan dan masyarakat yang ada di Turki, sehingga hati nurani mereka bergejolak untuk menuju perubahan Turki yang lebih baik lagi dan hal tersebut terlihat ketika secara perlahan kedigdayaan militer dalam mengawal konstitusi warisan Mustafa Kemal perlahan mencair dan mengarah pada perubahan-perubahan yang sesuai dengan kebutuhan dan perkembangan di Turki. Gelombang demokratisasi di seluruh penjuru dunia pada tahun 1980-an diiringi ge-lombang kesadaran politik masyarakat sipil di berbagai belahan dunia, dan khusus untuk Turki keinginan untuk menjadi bagian dari Uni Eropa prasyaratnya adalah menjalankan demokrasi utuh, turut membuka mata banyak orang di Turki. Mereka melihat gagasan sekularisme ala Mustafa Kemal telah kehilangan orientasi dan mencoba bermain jalur politik secara sehat, mereka mendirikan partai dan mengikuti pemilu secara konstitusional. (Ahmad Junaidi, 2016: 143)

Hal itu juga dijadikan sebagai momentum kebangkitan politik Islam oleh kalangan menengah muslim dan pengusung ide-ide Islam disusul pendirian partai-partai berbasis Islam. Meski demikian, dalam perjalanannya demokrasi ala Turki masih saja didominasi oleh Partai penguasa beraliran nasionalis sekuler, mereka cukup berpengaruh di Mahkamah Nasional, pengikut setia almarhum Mustafa Kemal. Akibatnya, banyak partai-partai berideologi Islam dibekukan karena alasan berideologi yang menurut mereka tidak sesuai dengan konstitusi Turki, di sini intervensi militer juga sangat kuat. Dengan kondisi yang 
berkembang saat itu, Islam tidak lagi selaku teras kedaulatan. Islam sudah dianggap sesuatu ajaran atau faham yang tidak relevan lagi dengan perkembangan zaman. Pendeknya, dalam gerakan mensekulerisasikan negara, aspek syariat tidak lagi mendapat tempat dalam pemerintahan. Namun ia tidak sama sekali menghentikan perjuangan Islam dan keimanan yang masih bertapak di sanubari rakyat. Namun tetap ada Tokoh Islam utama Turki yang selalu menjadi penentang terhadap faham Attartuk, Syeikh Said Nursi Bediuzzaman selalu melakukan perjuangan dalam usaha menyedarkan orang ramai tentang bahaya yang sedang dihadapi oleh Turki. Beliau diekori kemana saja dan pernah diintip ketika hendak bersembahyang supaya mematuhi larangan azan dilaungkan dalam bahasa Arab. Syeikhul Islam Turki, Sheikh Mustaffa Sabri telah mengeluarkan fatwa tentang sekulerisme. Katanya, penganut ajaran tersebut adalah terkeluar dari Islam. (Jhon Afrizal, 2012: 146) Walaupun hanya sebagian kecil yang mengikuti fatwanya.

Namun hal tersebut tidak menghalangi para pejuang yang mengusung konsep Islamisme di negara Turki, kembali ada sosok yang terkenal sebagai tokoh gerakan Islam, dan mendapatkan kehormatan sebagai "Seorang Pejuang Islam", atas perjuangannya yang gigih, tak mengenal lelah, sepanjang hidupnya untuk menegakkan cita-cita Islam di tengah-tengah kehidupan politik Turki yang sekuler. Masyarakat Turki mengenalnya dengan nama lengkap, Necmetin Erbakan. Ia membangun "Gerakan Islamis" di Turki, yang harus menghadapi kehidupan sekuler yang keras, dan kuatnya dominasi militer, yang menjadi 'garda depan' sistem sekuler di negeri yang pernah menjadi pusat kekhalifahan Islam. (Ahmad Junaidi, 2016: 145)

Berawal dengan memenangkan pemilu tahun 1996 oleh partai yang dipimpin sendiri dan partai yang mengususngnya yaitu partai Islam Refah, Erbakan kemudian melakukan kerjasama dengan pemimpin Partai Tanah Air, Tancu Ciller, dan kemudian membentuk pemerintahan Turki, dan Erbakan menjadi perdana menteri. Tetapi, umur pemerintahannya tidak panjang, hanya satu tahun, karena dibubarkan militer Turki, yang tidak ingin Erbakan mengembangkan pandangan- pandangannya yang Islamis itu, kemudian menjadi sebuah kebijakan Turki. (Peena, 2012)

Hal tersebut merupakan kasus penjegalan yang menimpa Necmekin Erbakan tahun 1997 saat memimpin dan merupakan salah satu contoh ketegangan nasionalis-Islamis yang masih saja mewarnai kultur politik Turki. Namun perjuangan Islamisasi di Turki tidak terhenti begitu saja, seperti yang diketahui, murid dari Necmekin Erbakan yaitu Recep Tayyip Erdogan bersama Abdullah Gul memegang tongkat estafet dalam mendirikan partai berbasis Islam. Langkah gigih dari keduanya dalam memeperjuangkan ideologi Islam di Turki memiliki kesamaan dengan guru mereka. Terbukti melalui partai AKP yang mereka dirikan pada tanggal 14 Agustus 2001, mendapat apresiasi dari masyarakat dengan melihat perkembangan serta keberhasilnnya berupa pemenangan pemilihan umum pada tahun 2002 . AKP pun menjadi partai yang berkuasa yang mendapatkan 367 kuris dari total 550 kursi di parlemen. Kemenangan AKP terulang lagi pada pemilihan umum tahun 2007, partai pemimpinan Recep Tayyip Erdogan itu memenangkan jabatan strategis yakni jabatan Presiden yang diduduki oleh Abdullah Gul, sedangkan Perdana Mentrinya diduduki oleh Recep Tayyip Erdogan dan menguasai mayoritas kursi di parlemen. Sepak terjang Erdogan dan kebij akannya, salah satunya adalah mengembalikan kebiasaan lama yaitu pengajaran Al Quran dan Hadits di sekolah-sekolah negeri di Turki yang sudah lama dihilangkan, dan kebebasan berhijab di kampus-kampus di Turki. Kemajuan pesat negara Turki dibawah kepemimpinan Erdogan sebagai Perdana Menteri membuat Turki kini disegani sebagai salah satu negara terkuat di Eropa. Dan membuat namanya semakin melambung sebagai salah satu pemimpin terbaik dunia. Sehingga pemilihan umum tahun 2011, AKP mendapat kepercayaan dari masyarakat untuk memenangkan kembali dan Erdogan menjabat sebagai Perdana Mentri priode berikutnya pada pemilihan umum untuk menyampaikan aspirasi masyarakat Turki. (Ahmad Junaidi, 2016: 147)

Ketika masa jabatannya sebagai Perdana Mentri Turki selesai pada tahun 2014, Recep Tayyip Erdogan kemudian mencalonkan diri sebagai Presiden Turki dengan dukungan dari partai AKP. Hasilnya pada tanggal 10 Agustus 2014 Erdogan berhasil terpilih sebagai Presiden Turki melalui pemilihan umum menggantikan presiden sebelumnya dengan masa jabatan selama lima tahun.

Keberhasilan Erdogan merebut hati rakyat Turki adalah bukan program ekonomi atau 'sekulernya' semata, tapi terutama karena program Islamisasinya yang mengesankan. Pesan Islam dari kebijakan-kbijakan politiknya yang dibawa 
damai oleh Erdogan menyebabkan ia dikagumi masyarakat dan terus dibenci oleh kaum sekuler ekstrim. Sebelum menjadi presiden, seperti yang telah disinggung penulis di atas, Erdogan telah konsisten memperjuangkan jilbab di Turki. Hingga dua anaknya harus ia sekolahkan di Amerika, karena pemerintah Turki melarang mahasiswa berjilbab. Hingga kini menjadi presiden, Erdogan pun terus konsisten menjalankan program islamisasinya, seperti membebaskan pakaian jilbab di seluruh sektor, melarang minuman keras, mendukung perjuangan Palestina, mendukung presiden Mursi yang digulingkan dan lain-lain.

\section{PENUTUP}

Pondasi sekularisasi yang dibangun oleh Mustafa Kemal Attatur telah memudar, para kemalis yang melanjutkan faham yang diajarkan Mustafa Kemal tidak mendapat respon baik dari masyarakat Turki. Para militer yang dulu panatif terhadap faham sekularisasi yang diajarkan Mustafa Kemal Attaur sudah berubah, mereka tidak menjadi nasionalis yang membabi buta, namun telah loyal kepada negara dan penguasa yang sah. Bahkan Attatur Turki saat ini telah memasuki era baru, kelompok Islamis moderat yang menguasai jalannya pemerintahan menunjukkan kemajuan diberbagai bidang yang mendapat dukungan besar dari masyarakat. Perubahan konstitusi sedikit demi sedikit dilakukan untuk mengurangi bahkan menghilangkan peran militer yang besar di dalam politik. Munculnya tokoh-tokoh Islam yang berada dipemerintahan mampu merubah negara sekuler menjadi negara yang menjunjung tinggi Islam dan bahkan saat ini, Turki bersama Erdogan telah menjadi kekuatan yang diperhitungkan di Dunia.

\section{DAFTAR PUSTAKA}

Ahmad Junaidi. 2016. Kebijakan Politik Recep Tayyib Erdogan dan Islamisme Turki Kontemporer, IN RIGHT Jurnal Agama dan HakAzazi Manusia, Vol. 6, No. 1.

Asmal May. 2006. Peradaban Islamdalam Lintasan Sejarah, Jakarta: Citra Harta Prima.

Jhon Afrizal. 2012. Gerakan Sosial Politik Islam Dunia, Asas Perubaban Skenario Politik Negara, Pekanbaru: Jurnal Sosial Budaya, Vol. 9, No.1.

Jules Archer. 2004. Kisah Para Diktator Biografi Para Penguasa Politik Fasis Komunis Despotis dan Tiran. Yogyakarta: Narasi.
Imron Mustafa, Turki Antara Sekularisme dan Aroma Islam; Studi atas Pemikiran Niyazi Berkes, Surabaya: Jurnal Elbanat, Vol. 6, No. 1.

M. Arfan Mu'ammar. Kritike Terhadap Sekularisasi Turki, Telaah Historis Transformasi Turki Usmani. Surabaya: Jurnal Episteme, Vol. 11, No. 1.

Muhammad Iqbal, dan Amin Husein Nasution. 2010. Pemikiran Politik Islam Dari Masa Klasik Hingga Indonesia Kontemporer. Bandung: Kencana.

Niyazi Berkes. 1953. The Development of Secularism in Turkey. Montreal: McGill University Press.

Nina M. Armando (ed.), Ensiklopedi Islam Jilid 8 Jakarta:PT. Ichtiar Baru Van Hoeve, 2005

Nur Aliyah Zainal. 2016. Analisis Tentang Dekemalisasi Di Turki Pasca Ataturk. Alauddin Makassar: Jurnal Politik Profetik Volume 04, No. 1.

Peena. 2012. Biografi Tokoh Dunia Islam, http://pena-mylife.blogspot.co.id/2012/04/ biografi-necmettin-erbakan.html.

Solihun. 2013. Negra Turki Pada Masa Kepemimpinan Mustafa Kemal Attatur Tabun 1923. 1950. Depok: Jurnal FIB. 